\title{
Resource-Saving Methods for Growing Rice in the Krasnodar Territory
}

\author{
Igor Prikhodko*, Stanislav Vladimirov and Daniil Alexandrov \\ Kuban State Agrarian University named after I.T. Trubilin, 13, Kalinina str., Krasnodar, 350044, Russia
}

\begin{abstract}
The world practice of rice cultivation has shown that rice cultivation by traditional methods for Russia is labor-intensive, resource-intensive, ineffective with low profitability, and often unprofitable production. As a result, traditional methods of flooding rice paddies in Russia are faced with a shortage and high cost of irrigation water and a reduction in rice irrigation systems, i.e., areas suitable for rice cultivation. For solving the problem of unprofitable rice production, an analysis of the world practice of rice production has been implemented. The analysis showed that the most optimal solution for the natural and climatic conditions of the Krasnodar Territory is the cultivation of rice using sprinkler irrigation and drip irrigation. Further analysis showed that drip irrigation is the most promising way of growing rice, which has many undeniable advantages. The main advantages of drip irrigation are the low irrigation rate, labor intensity, and energy intensity of rice production. Therefore, the article proposes a pioneering Russian ridge cultivation method for rice cultivation on the lands of the irrigated rice fund with drip irrigation under plastic and/or biodegradable perforated film. This method will make it possible to radically revise the principles of rice cultivation, form a new generation of rice crop rotations with the inclusion of melons and vegetables in them, and carry out rice production on previously rainfed lands. The implementation of the method has proven the effectiveness and feasibility of our research.
\end{abstract}

\section{Introduction}

China is the world leader in rice production [1-3]. This fact is primarily associated with favorable natural and climatic conditions, which contribute to obtaining high rice yields. In Russia, the leader in rice production is the Krasnodar Territory [4-5]. In the Krasnodar Territory, the history of rice production has more than a century of history. However, introducing new methods of rice cultivation is very low [6-8]. This circumstance is explained by bureaucratic difficulties, considerable material, energy, technological, and labor costs of the transition to new eco-resource-saving rice production technologies. In this regard, many studies in increasing rice production profitability have not been completed and/or tested on rice irrigation systems [9].

Consequently, the task should be set to obtain guaranteed high rice yields to reduce anthropogenic and environmental pressure on rice irrigation systems. For accomplishing this task, it is necessary to consider all the accumulated foreign and domestic experience in rice cultivation. Based on the analysis of the available experience, it is necessary to develop recommendations for workers in the rice-growing sector in Russia. The use of these recommendations will make it possible to make timely management decisions to obtain programmed rice yields, optimize the use of resources available on the farm, reduce the ecological and anthropogenic load and preserve the agro-resource potential of the soils of the rice irrigation system.

\section{Materials and methods}

The method of cultivating rice on the checks of a rice irrigation system with surface drip irrigation under polyethylene and the biodegradable mulching perforated film was implemented as follows.

Autumn work is carried out in the first year of implementing the ridge method of rice cultivation on the lands of the irrigated rice fund with surface drip irrigation under polyethylene and/or biodegradable mulch perforated film. After harvesting, the preceding plants perform the following actions at a time:

- cutting and restoration of peripheral check grooves with a depth of $0.4-0.6 \mathrm{~m}$;

- alignment of the surface of checks;

- primary tillage to a depth of $0.25-0.30 \mathrm{~m}$;

- cleaning of irrigation and waste canals;

- backfilling of check rollers up to design marks;

- deep loosening (chiseling) to a depth of $0.16-0.18 \mathrm{~m}$;

- disking with the incorporation of organic fertilizers to a depth of $0.10-0.12 \mathrm{~m}$ and an application rate of 40-50 tons per hectare of manure or green fertilizer.

In the spring of the first year of implementation of the method, the following actions are performed:

- harrowing with tooth harrows in two tracks to a depth of $0.08 \mathrm{~m}$;

\footnotetext{
Corresponding author: prihodkoigor2012@yandex.ru
} 
- the formation of ridges by making depressions in the form of inter-ridge technological passages, which are covered with non-woven geosynthetic material, while the size and distance between the ridges depend on the technical characteristics of the technique used for cultivating rice and related crops of rice crop rotation.

Next, an annual spring-autumn technological cycle of work is performed, which includes the following operations:

- rolling the soil of the ridges;

- assembly of a drip irrigation system, including a fertigation system,

- laying on the ridges of drip tapes with a pitch between outlets $-20 \mathrm{~cm}$, diameter, and wall thickness of the drip tape $-16 \mathrm{~mm}$ and $0.2 \mathrm{~mm}$, respectively. Moreover, the water outflow of the drip tape outlet in $1 / \mathrm{h}$ per $1 \mathrm{~m}$ is taken from the condition of ensuring the required moisture content in a given soil layer for rice crop rotation. In this case, the distance between the drip tapes is $24 \mathrm{~cm}$. The drip tape is laid on the ridges in compliance with the irrigation conditions with one drip tape of two rows of perforations on the mulching film. The perforation diameter is $6 \mathrm{~cm}$, the distance between which in a row and between adjacent rows is $6 \mathrm{~cm}$.

Growing rice seedlings are in an amount of 1 to 3 plants in one nutrient pot with a diameter of $6 \mathrm{~cm}$ in the substrate. Substrate components: highly fertile field land, sod land, hummus, high peat, coarse sand are taken in such a ratio that the humus content in the substrate is not less than $60 \%$, and the substrate density is $0.8-1.0 \mathrm{~g} / \mathrm{cm}^{3}$, the porosity is $80-90 \%$, air content - not less than 15-20\% with the addition of microelements to the substrate before planting rice seeds in the amount of $75 \%$ of the full norm of $\mathrm{N}_{150} \mathrm{P}_{60} \mathrm{~K}_{45}$ in $\mathrm{kg}$ a.i./ha and one feeding with nitrogen fertilizers in the phase of 2-3 sheets with the norm $\mathrm{N}_{40}$ in $\mathrm{kg}$ a.w./ha.

During the period of growing seedlings, the following parameters are maintained:

- temperature regime, namely during the day 24-26 ${ }^{\circ} \mathrm{C}$, in cloudy weather $-20-22{ }^{\circ} \mathrm{C}$, at night $18-20{ }^{\circ} \mathrm{C}$;

- optimal pre-irrigation substrate moisture content at the level of $80 \%$ of the lowest moisture capacity, relative air humidity $-70-80 \%$,

- illumination: the first three days, the additional lighting time is 24 hours; after the third day - at least 12-14 hours, depending on daylight hours and weather conditions.

Before planting rice, pre-planting irrigation is performed with a rate providing soil moisture of $90 \%$ of the lowest moisture capacity in a layer of $0.6 \mathrm{~m}$. After that, the soil surface is treated with soil herbicides. And then they cover the ridges with a perforated mulch film.

Planting rice seedlings is in the perforation of the mulching film in the phase of 6-7 leaves with green color, a well-developed root system, and not infected with pests and diseases. In this case, 1-2 days before planting rice seedlings in open ground, seedlings are sprayed with biologically active substances.

Drip irrigation of rice through a drip irrigation system during the growing season of rice with the frequency and rate of irrigation, depending on the compliance with the condition of ensuring constant soil moisture of $80 \%$ of the lowest moisture capacity in a layer of $0.4 \mathrm{~m} \mathrm{[10]}$.

Application of $25 \%$ of the complete norm of mineral fertilizers with two equal rates of $\mathrm{N}_{25} \mathrm{P}_{20} \mathrm{~K}_{15}$ in $\mathrm{kg}$ ai/ha in the phase of 8-9 leaves after complete survival and the tillering phase by fertigation through a drip irrigation system. At the same time, the total rate can be adjusted from the recommended one, depending on the agricultural background and the adopted crop rotation.

Drip irrigation of rice through a drip irrigation system during the growing season of rice is carried out with the frequency and rate of irrigation, depending on compliance with the condition of ensuring constant soil moisture of $80 \%$ of the lowest moisture capacity in a layer of $0.4 \mathrm{~m} \mathrm{[11].}$

Spraying is carried out according to the following scheme:

- biologically active substances in the germination phase of young rice seedlings and at the end of the tillering phase before the start of stemming [12];

- pesticides in the tillering phase,

- fungicides in the tube exit phase and again after 20-25 days;

- insecticides during the growing season when pests exceed the economic threshold of harmfulness.

Rice harvesting with subsequent pre-planting irrigation before planting accompanying rice crop rotation and creating the necessary and sufficient moisture and depth of soil moisture for planting a crop through a drip irrigation system with the introduction of mineral fertilizers. The rates and timing of applying mineral fertilizers correspond to the accepted technology to produce this crop [13].

Growing seedlings and/or planting accompanying crops of rice crop rotation with the introduction of mineral fertilizers, treatment of crops with pesticides, fungicides, and insecticides. The rates and timing of the additions correspond to the accepted technology to produce this crop [14].

Drip irrigation of accompanying crops of rice crop rotation is carried out through a drip irrigation system during the growing season. The frequency and irrigation rates depend on the observance of the conditions for ensuring soil moisture in the soil layer required by the technology of culture production, which is necessary for the normal development of the culture [15].

After harvesting crops of rice crop rotation, mulching perforated film and drip tapes are collected from the ridges. Moreover, in the case of using a biodegradable mulch film, it is left on the ridges. After that, peeling is carried out in two tracks to a depth of 0.06-0.08 m.

In subsequent years of rice cultivation, in the spring, the geometry of the ridges is restored with loosening to a depth of $0.06-0.08 \mathrm{~m}$ of the upper layer of the ridges. After that, the annual spring-autumn technological cycle of work is repeated.

Figures 1-3 represent the developed method of rice bed cultivation on the lands of the irrigated rice fund with surface drip irrigation under plastic and/or biodegradable perforated film. 


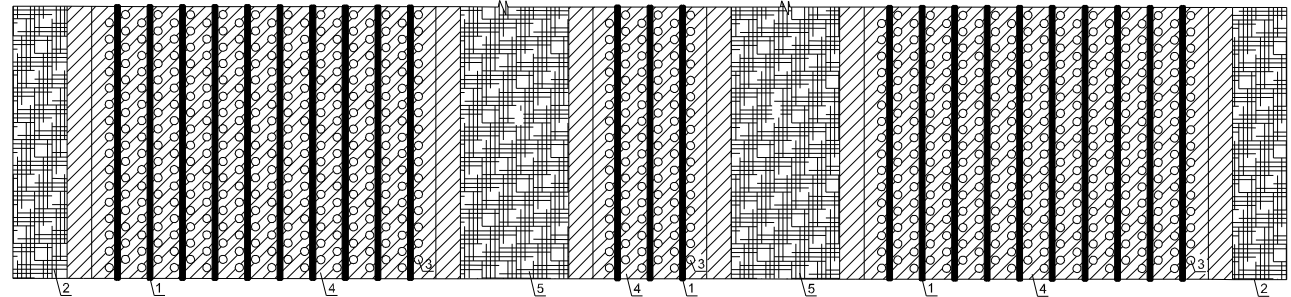

Fig. 1. flow chart of one capture, taking into account the technical characteristics of soil cultivation and harvesting equipment at LLC "Chernoerkovskoe" of the Slavyansky district of the Krasnodar Territory during the cultivation of rice and related crops of rice crop rotation on drip irrigation with the laying of a drip tape on the beds under a mulching film, including biodegradable: 1 - drip tape; 2 technological passage; 3 - round perforation in the mulch film for planting crops; 4 - mulching film; 5 - technological passage; 6 - ridge

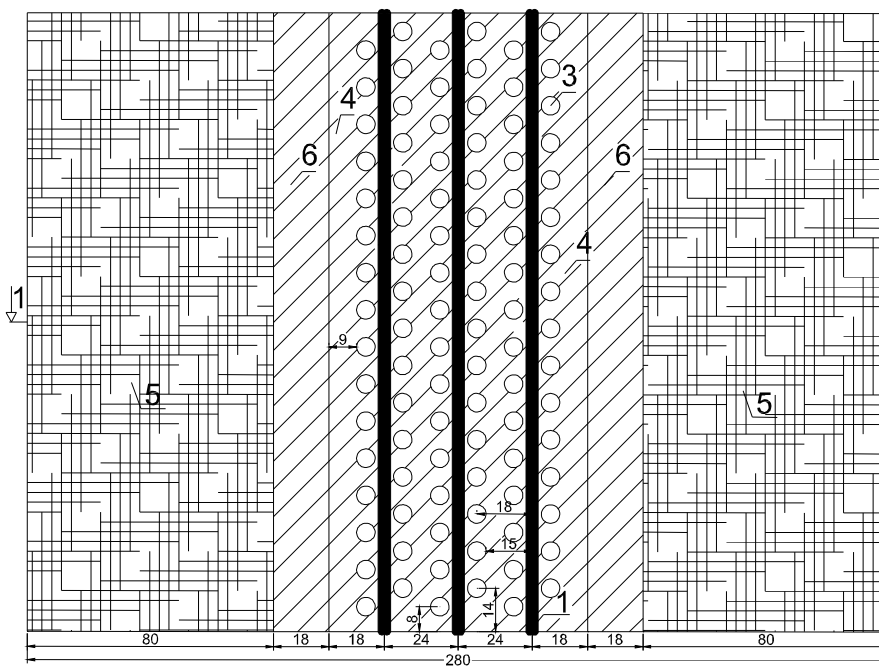

Cutting 1-1

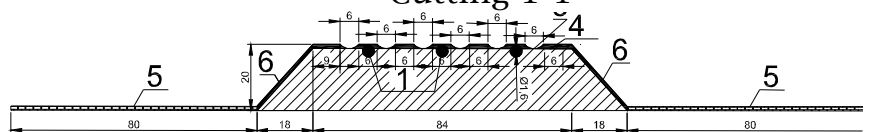

Fig. 2. A fragment of the central part of the technological scheme of one capture, taking into account the technical characteristics of soil cultivation and harvesting equipment when cultivating rice and related crops of rice crop rotation on surface drip irrigation with a drip tape laying on the beds under mulching film, including biodegradable: 1 - drip tape; 2 - technological passage; 3 - round perforation in the mulching film for planting crops; 4 - mulching film; 5 - technological passage; 6 - ridge

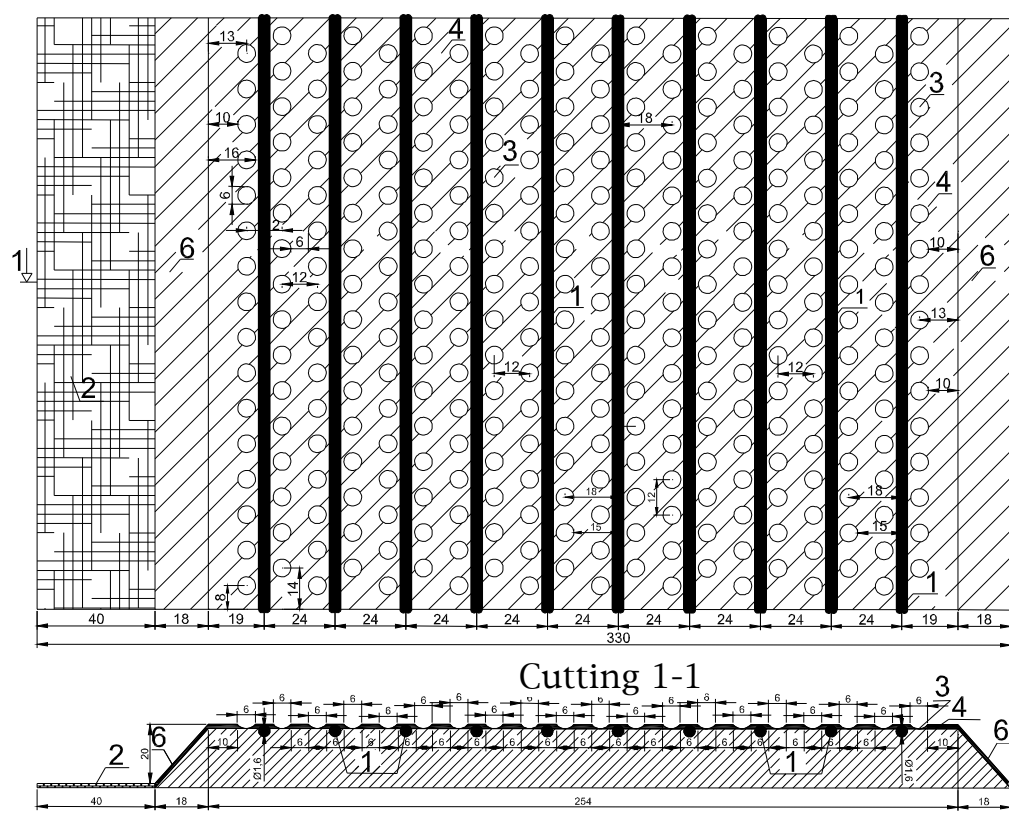

Fig. 3. Fragment of the left part of the technological scheme of one capture, taking into account the technical characteristics of soil cultivation and harvesting equipment when cultivating rice and related crops of rice crop rotation on surface drip irrigation with drip tape laying on the beds under mulching film, including biodegradable: 1 - drip tape; 2 - technological passage; 3 - round perforation in the mulch film for planting crops; 4 - mulching film; 5 - technological passage; 6 - ridge 


\section{Results and its discussion}

The proposed approach to rice cultivation can be called adaptive. The cultivation of rice and related crops of rice crop rotation is carried out using surface drip irrigation with the laying of drip tape on the ridges under the mulch film. We offer an individual approach to the development of a technological scheme of one capture based on the technical equipment of the farm, as well as other available resources (material, labor, energy). Approbation of the method of rice cultivation took place in LLC "Chernoerkovskoe" of the Slavyansky district (2nd branch) of the Krasnodar Territory on an area of 4.5 hectares (one rice check). During approbation, a technological scheme of one capture was developed, considering the technical characteristics of the tillage and harvesting equipment of the farm (Figure 1-3). The farm uses the scheme of an engineering rice plot of the Krasnodar type [16]. The cultivated rice crop was the Rapan variety. The predecessor in the first year of the implementation of the method is rice.

In the experimental field from 2016 to 2019, the following crop rotation was applied: 2016: rice (seedlings) + tomatoes (seedlings); 2017: rice (seedlings) + peas (seed); 2018: rice (seedlings) + sweet pepper (seedlings); 2019: rice (seedling) + soybean (seed).

The efficiency of rice cultivation has been proven because of approbation of the method of rice cultivation with drip irrigation under polyethylene and/or biodegradable mulch perforated film. The place of approbation is LLC "Chernoerkovskoe" of the Slavyansky district, with an area of 4.5 hectares, where in 2016-2019, rice was cultivated on drip irrigation under mulching perforated film (tables 1, 2).
Table 1. Biometric and quantitative characteristics of rice

\begin{tabular}{|c|c|c|c|c|c|}
\hline \multirow{2}{*}{ No. } & \multirow{2}{*}{ Name } & \multicolumn{4}{|c|}{ Years } \\
\hline & & 2016 & 2017 & 2018 & 2019 \\
\hline 1 & Vegetation period & 117 & 114 & 116 & 115 \\
\hline 2 & Plant height, $\mathrm{cm}$ & 90.4 & 91.8 & 92.4 & 93.2 \\
\hline 3 & Panicle length, $\mathrm{cm}$ & 16.2 & 16.6 & 16.9 & 17.1 \\
\hline 4 & $\begin{array}{l}\text { The number of spikelets in a } \\
\text { panicle, pcs. }\end{array}$ & 194 & 199 & 203 & 205 \\
\hline 5 & $\begin{array}{l}\text { Number of grains, pcs.: } \\
\text { - total } \\
\text { - empty }\end{array}$ & $\begin{array}{c}190 \\
4 \\
\end{array}$ & $\begin{array}{c}190 \\
3 \\
\end{array}$ & $\begin{array}{c}195 \\
4 \\
\end{array}$ & $\begin{array}{c}193 \\
2 \\
\end{array}$ \\
\hline 6 & Empty grain, \% & 2.1 & 2.1 & 2.1 & 2.1 \\
\hline 7 & $\begin{array}{l}\text { Caryopsis length to width } \\
\text { ratio }(1 / b)\end{array}$ & 2.2 & 2.2 & 2.3 & 2.3 \\
\hline 8 & $\begin{array}{l}\text { Weight g/plant: } \\
\text { - grains } \\
\text { - straw }\end{array}$ & $\begin{array}{l}7.6 \\
7.0\end{array}$ & $\begin{array}{l}7.6 \\
6.7 \\
\end{array}$ & $\begin{array}{l}7.8 \\
6.9\end{array}$ & $\begin{array}{l}7.7 \\
7.1\end{array}$ \\
\hline 9 & Straw: grain ratio & 0.92 & 0.88 & 0.88 & 0.92 \\
\hline 10 & Weight of 1000 grains, $g$ & 28 & 27 & 29 & 30 \\
\hline 11 & $\begin{array}{l}\text { Average density of crops, } \\
\text { plants } / 1 \mathrm{~m}^{2} \\
1 \text { plant per hole } \\
2 \text { plants per hole } \\
3 \text { plants per hole }\end{array}$ & \multicolumn{4}{|c|}{$\begin{array}{c}68 \\
136 \\
204\end{array}$} \\
\hline 12 & Land use ratio & \multicolumn{4}{|c|}{77.6} \\
\hline 13 & $\begin{array}{l}\text { Productivity (3 plants per } \\
\text { hole), t/ha }\end{array}$ & 12.1 & 12.1 & 12.4 & 12.3 \\
\hline 14 & Control yield, t / ha & 10.5 & 10.7 & 10.8 & 10.5 \\
\hline 15 & $\begin{array}{l}\text { Increase in yield } \\
-\mathrm{t} / \mathrm{ha} \\
-\%\end{array}$ & $\begin{array}{l}1.6 \\
13 \\
\end{array}$ & $\begin{array}{l}1.4 \\
12 \\
\end{array}$ & $\begin{array}{l}1.6 \\
13\end{array}$ & $\begin{array}{l}1.8 \\
15\end{array}$ \\
\hline
\end{tabular}

Table 2. Dynamics of the reclamation state of soils during the cultivation of rice on drip irrigation under a mulching perforated film (experimental field in OOO Chernoerkovskoye, Slavyansky district, with an area of 4.5 hectares for 2016-2019)

\begin{tabular}{|c|c|c|c|c|c|}
\hline № & Name & Unit of measurement & Year & Indicator value & $\begin{array}{l}\text { Assessment of the } \\
\text { reclamation state of soils }\end{array}$ \\
\hline 1 & 2 & 3 & 4 & 5 & 6 \\
\hline \multirow{8}{*}{1} & \multirow{8}{*}{ Groundwater level / Groundwater salinity } & \multirow{8}{*}{$\mathrm{m} /(\mathrm{g} / 1)$} & \multirow{2}{*}{2016} & 1.5 & \multirow{2}{*}{1} \\
\hline & & & & 2.98 & \\
\hline & & & \multirow{2}{*}{2017} & 1.6 & \multirow{2}{*}{1} \\
\hline & & & & 2.82 & \\
\hline & & & \multirow{2}{*}{2018} & 1.7 & \multirow{2}{*}{1} \\
\hline & & & & 2.64 & \\
\hline & & & \multirow{2}{*}{2019} & 1.8 & \multirow{2}{*}{1} \\
\hline & & & & 2.28 & \\
\hline \multirow{4}{*}{2} & \multirow{4}{*}{ Soil pH } & \multirow{4}{*}{-} & 2016 & 6.7 & 1 \\
\hline & & & 2017 & 6.8 & 1 \\
\hline & & & 2018 & 7.0 & 1 \\
\hline & & & 2019 & 7.0 & 1 \\
\hline \multirow{4}{*}{3} & \multirow{4}{*}{ Humus content } & \multirow{4}{*}{$\%$} & 2016 & 3.9 & 4 \\
\hline & & & 2017 & 3.9 & 4 \\
\hline & & & 2018 & 4.0 & 3 \\
\hline & & & 2019 & 4.2 & 3 \\
\hline \multirow{4}{*}{4} & \multirow{4}{*}{$\begin{array}{l}\text { Stocks of humus in the layer } \\
0-100 \mathrm{~cm}\end{array}$} & \multirow{4}{*}{ t/ha } & 2016 & 184 & 4 \\
\hline & & & 2017 & 189 & 4 \\
\hline & & & 2018 & 194 & 4 \\
\hline & & & 2019 & 202 & 3 \\
\hline \multirow{4}{*}{5} & \multirow{2}{*}{$\begin{array}{l}\text { Availability of hydrolyzable nitrogen } \\
\text { (according to Tyunin - Kononova) }\end{array}$} & \multirow{2}{*}{$\mathrm{mg} / 100 \mathrm{~g}$} & 2016 & 4.9 & 4 \\
\hline & & & 2017 & 5.3 & 3 \\
\hline & \multirow{2}{*}{ Salinity type } & & 2018 & 5.4 & 3 \\
\hline & & & 2019 & 5.7 & 3 \\
\hline
\end{tabular}




\begin{tabular}{|c|c|c|c|c|c|}
\hline \multirow{4}{*}{6} & \multirow{4}{*}{$\begin{array}{l}\text { Availability of mobile phosphorus } \\
\text { (according to Chirikov) }\end{array}$} & \multirow{4}{*}{$\mathrm{mg} / 100 \mathrm{~g}$} & 2016 & 4.2 & 4 \\
\hline & & & 2017 & 4.6 & 4 \\
\hline & & & 2018 & 5.0 & 4 \\
\hline & & & 2019 & 5.2 & 3 \\
\hline \multirow{4}{*}{7} & \multirow{4}{*}{$\begin{array}{l}\text { Availability of mobile potassium } \\
\text { (according to Chirikov) }\end{array}$} & \multirow{4}{*}{$\mathrm{mg} / 100 \mathrm{~g}$} & 2016 & 3.5 & 4 \\
\hline & & & 2017 & 3.8 & 4 \\
\hline & & & 2018 & 4.1 & 3 \\
\hline & & & 2019 & 4.8 & 3 \\
\hline \multirow{4}{*}{8} & \multirow{4}{*}{ Enrichment with nitrogen $\mathrm{C}: \mathrm{N}$} & \multirow{4}{*}{-} & 2016 & 11.2 & 4 \\
\hline & & & 2017 & 10.3 & 3 \\
\hline & & & 2018 & 9.7 & 3 \\
\hline & & & 2019 & 9.1 & 3 \\
\hline \multirow{4}{*}{9} & \multirow{4}{*}{$\begin{array}{l}\text { Content of exchangeable magnesium in } \\
\text { soil }(\mathrm{MgO})\end{array}$} & \multirow{4}{*}{$\mathrm{mg} / \mathrm{kg}$ soil } & 2016 & 57 & 4 \\
\hline & & & 2017 & 62 & 3 \\
\hline & & & 2018 & 68 & 3 \\
\hline & & & 2019 & 74 & 3 \\
\hline \multirow{4}{*}{10} & \multirow{4}{*}{ Content of sulfate (mobile) sulfur, $S$} & & 2016 & 9.4 & 4 \\
\hline & & & 2017 & 9.9 & 4 \\
\hline & & $\mathrm{mg} / \mathrm{kg}$ soll & 2018 & 10.4 & 3 \\
\hline & & & 2019 & 10.8 & 3 \\
\hline & & & 2016 & 29 & 4 \\
\hline & & & 2017 & 32 & 4 \\
\hline 11 & Degree of saturation with bases, $V$ & $\%$ & 2018 & 38 & 4 \\
\hline & & & 2019 & 46 & 3 \\
\hline & & & 2016 & 0.76 & 4 \\
\hline & & & 2017 & 0.84 & 4 \\
\hline 12 & Structural coefficient, $K_{\text {str }}$ & - & 2018 & 0.91 & 4 \\
\hline & & & 2019 & 0.99 & 3 \\
\hline & & & 2016 & 40 & 5 \\
\hline & & & 2017 & 47 & 4 \\
\hline 13 & Total porosity & $\%$ & 2018 & 53 & 3 \\
\hline & & & 2019 & 61 & 2 \\
\hline & & & 2016 & 1.30 & 3 \\
\hline & Soil density & & 2017 & 1.26 & 2 \\
\hline 14 & (according to N.A.Kachinsky) & $\mathrm{g} / \mathrm{cm}^{3}$ & 2018 & 1.21 & 2 \\
\hline & & & 2019 & 1.17 & 1 \\
\hline & & & 2016 & 19.0 & 3 \\
\hline 15 & Nitrification canacity of soil & & 2017 & 24.0 & 3 \\
\hline 15 & Nitrification capacity of soil & $\mathrm{mg} \mathrm{NO}_{3} / \mathrm{kg}$ & 2018 & 29.0 & 3 \\
\hline & & & 2019 & 34.0 & 2 \\
\hline & & & 2016 & 22 & 4 \\
\hline & Content of water-resistant aggregates in & & 2017 & 28 & 4 \\
\hline 16 & the layer $0-30 \mathrm{~cm}$ & $\%$ & 2018 & 35 & 3 \\
\hline & & & 2019 & 41 & 2 \\
\hline & & & 2016 & 1.4 & 3 \\
\hline & & & 2017 & 1.3 & 3 \\
\hline 17 & Salt content / & $\% 1-$ & 2018 & 1.1 & 3 \\
\hline & & & 2019 & 0.8 & 2 \\
\hline & "Total effect" of toxic $\mathrm{CO}_{3}{ }^{2-}, \mathrm{HCO}_{3}{ }^{-}, \mathrm{Cl}^{-}$, & & 2016 & 1.94 & 3 \\
\hline 18 & $\mathrm{SO}_{4}^{2-}$ & & 2017 & 1.76 & 3 \\
\hline 18 & (N.I.Bazilevich, & $\mathrm{mg} \cdot$ eq. Cl- & 2018 & 1.43 & 3 \\
\hline & E.I. Pankova) & & 2019 & 1.08 & 2 \\
\hline & & & 2016 & 9.8 & 4 \\
\hline 19 & & & 2017 & 11.4 & 3 \\
\hline 19 & Rate of $\mathrm{CO}_{2}$ emission in soil & $\mathrm{mg} \mathrm{CO} 2 /(10 \mathrm{~g} /$ day $)$ & 2018 & 13.9 & 3 \\
\hline & & & 2019 & 15.6 & 2 \\
\hline & & Trace element $\mathrm{c}$ & & & \\
\hline & & & 2016 & 19 & 0,8 \\
\hline & Manganese (Mn) & & 2017 & 21 & 0,6 \\
\hline & (in $0.1 \mathrm{n} \mathrm{H}_{2} \mathrm{O}_{4}$ ) & & 2018 & 24 & 0,6 \\
\hline 20 & & & 2019 & 26 & 0,6 \\
\hline & & $\mathrm{mg} / \mathrm{kg}$ soil & 2016 & 1.80 & 0,6 \\
\hline & Copper $(\mathrm{Cu})$ & & 2017 & 2.10 & 0,6 \\
\hline & (in $0.1 \mathrm{n} . \mathrm{KCl}$ ) & & 2018 & 2.40 & 0,6 \\
\hline & & & 2019 & 2.50 & 0,6 \\
\hline
\end{tabular}




\begin{tabular}{|c|c|c|c|}
\hline \multirow{3}{*}{$\begin{array}{c}\text { Zinc (Zn) } \\
\text { (in } 0.1 \mathrm{n} . \mathrm{KCl})\end{array}$} & 2016 & 0.40 & 0,8 \\
\hline & 2017 & 0.60 & 0,8 \\
\hline & 2018 & 0.80 & 0,8 \\
\hline & 2019 & 1.10 & 0,6 \\
\hline \multirow{4}{*}{$\begin{array}{l}\text { Cobalt }(\mathrm{Co}) \\
\left.\text { (in } 0.1 \mathrm{n} . \mathrm{HNO}_{3}\right)\end{array}$} & 2016 & 1.10 & 0,8 \\
\hline & 2017 & 1.40 & 0,8 \\
\hline & 2018 & 1.80 & 0,6 \\
\hline & 2019 & 2.10 & 0,6 \\
\hline \multirow{4}{*}{$\begin{array}{l}\text { Molybdenum (Mo) } \\
\text { (in oxalate extract) }\end{array}$} & 2016 & 0.18 & 0,8 \\
\hline & 2017 & 0.21 & 0,6 \\
\hline & 2018 & 0.25 & 0,6 \\
\hline & 2019 & 0.28 & 0,6 \\
\hline \multirow{8}{*}{$\begin{array}{l}\text { The sum of the points of the indicators of the reclamation state of the soil } \\
\text { Assessment of the reclamation state of the soil }\end{array}$} & \multirow{2}{*}{2016} & \multicolumn{2}{|c|}{71} \\
\hline & & \multicolumn{2}{|c|}{ Satisfactorily } \\
\hline & \multirow{2}{*}{2017} & \multicolumn{2}{|c|}{64} \\
\hline & & \multicolumn{2}{|c|}{ Satisfactorily } \\
\hline & \multirow{2}{*}{2018} & \multicolumn{2}{|c|}{59} \\
\hline & & \multicolumn{2}{|c|}{ Satisfactorily } \\
\hline & \multirow{2}{*}{2019} & \multicolumn{2}{|c|}{48} \\
\hline & & \multicolumn{2}{|c|}{ Good } \\
\hline
\end{tabular}

We carried out row cultivation of rice on surface drip irrigation under polyethylene and perforated mulch film on the lands of the irrigation fund. Tables 1 and 2 show that this method made it possible to increase rice yield by up to $15 \%$ in 2019 and improve the reclamation state of soils from "satisfactory" to "good".

\section{Conclusions}

The leading indicators of the effectiveness of the claimed method are:

- annual average decrease in the irrigation rate by five times relative to the traditional technology of rice cultivation by flooding;

- reduction of labor intensity by $35-40 \%$;

- reduction of the cost of rice production by an average of $20 \%$;

- reduction of doses of introduced macro and microelements by an average of $30 \%$;

- increase in profitability by $22 \%$.

\section{References}

1. S.S. Girsang, T.Q. Correa Jr, J.R. Quilty, P.B. Sanchez, R.J. Buresh, Soil aeration and relationship to inorganic nitrogen during aerobic cultivation of irrigated rice on a consolidated land parcel, Soil and Tillage Res., 202, 104647 (2020), DOI: org/10.1016/j.still.2020.104647

2. G. Arbat, S. Cufí, M. Duran-Ros, J. Pinsach, J. PuigBargués, J. Pujol, F.R. de Cartagena, Modeling approaches for determining dripline depth and irrigation frequency of subsurface drip irrigated rice on different soil textures, Water (Switzerland), 12(6), 1724 (2020)

3. H. Chen, W. Zeng, Y. Jin, Y. Zha, B. Mi, S. Zhang, Development of a water logging analysis system for paddy fields in irrigation districts, J. of Hydrol., 591, 125325 (2020)
4. S. Majumder, P. Banik, Inhibition of arsenic transport from soil to rice grain with a sustained field-scale aerobic rice cultural practice, J. of Envir. Manag., 279, $111620 \quad$ (2021), DOI: org/10.1016/j.jenvman.2020.111620

5. M. Ishfaq, N. Akbar, Sh.A. Anjum, M. Anwar-Ij1Haq, Growth, yield and water productivity of dry direct seeded rice and transplanted aromatic rice under different irrigation management regimes, J. of Integrat. Agricult., 19(11), 2656-2673 (2020)

6. Z. Chen, P. Li, S. Jiang, H. Chen, J. Wang, C. Cao, Evaluation of resource and energy utilization, environmental and economic benefits of rice watersaving irrigation technologies in a rice-wheat rotation system, Sci. of The Total Envir., 757, 143748 (2021)

7. R. Joshia, B. Singh, A. Shukla, Evaluation of elite rice genotypes for physiological and yield attributes under aerobic and irrigated conditions in tarai areas of western Himalayan region, Current Plant Biol., 13, 45-52 (2018), DOI: org/10.1016/j.cpb.2018.05.001

8. M.A.B. Pinto, J.M.B. Parfitt, L.C. Timm, L.C. Faria, G. Concenço, L. Stumpf, B.G. Nörenberg, Sprinkler irrigation in lowland rice: Crop yield and its components as a function of water availability in different phenological phases, Field Crops Res., 248, 107714

(2020), DOI: org/10.1016/j.fcr.2020.107714

9. F. Monaco, G. Sali, How water amounts and management options drive Irrigation Water Productivity of rice. A multivariate analysis based on field experiment data, Agricult. Water Manag., 195, 47-57 (2018)

10. T. Safronova, S. Vladimirov, I. Prikhodko, A. Sergeyev, Optimization problem in mathematical modeling of technological processes of economic activity on rice irrigation systems, E3S Web of Conf., 210, $05014 \quad$ (2020), DOI: org/10.1051/e3sconf/202021005014 
11. S. Vladimirov, T. Safronova, I. Prikhodko, A probabilistic model of the process of land reclamation management, Int. agricult. J., 62(4), 171-185 (2019), DOI: 10.24411/2588-0209-201910093

12. D.P. Patel, A. Dasb, G.C. Munda, P.K. Ghosh, Ju.S. Bordoloi, M. Kumar, Evaluation of yield and physiological attributes of high-yielding rice varieties under aerobic and flood-irrigated management practices in mid-hills ecosystem, Agricult. Water Manag., 97(9), 1269-1276 (2010), DOI: org/10.1016/j.agwat.2010.02.018

13. A. López-Piñeiro, D. Peña, Á. Albarrán, J. SánchezLlerena, D. Becerra, D. Fernández, S. Gómez, Environmental fate of bensulfuron-methyl and MCPA in aerobic and anaerobic rice-cropping systems, J. of Envir. Manag., 237, 44-53 (2019), DOI: org/10.1016/j.jenvman.2019.02.058

14. P. Vijayaraghavareddy, Yi. Xinyou, P.C. Struik, U. Makarla, Sh. Sreeman, Responses of Lowland,
Upland and Aerobic Rice Genotypes to Water Limitation During Different Phase, Rice Sci., 27(4), 345-354 (2020), DOI: org/10.1016/j.rsci.2020.05.009

15. M.D.M. Kadiyala, J.W. Jones, R.S. Mylavarapu, Y.C. Li, M.D. Reddy, Identifying irrigation and nitrogen best management practices for aerobic ricemaize cropping system for semi-arid tropics using CERES-rice and maize models, Agricult. Water Manag., 149, 23-32 (2015), DOI: org/10.1016/j.agwat.2014.10.019

16. S.F. Islam, B.O. Sander, J.R. Quilty, A. Neergaard, Ja.W. Groenigen, L.S. Jensen, Mitigation of greenhouse gas emissions and reduced irrigation water use in rice production through water-saving irrigation scheduling, reduced tillage and fertiliser application strategies, Sci. of The Total Envir., 739, 140215 (2020),

DOI: org/10.1016/j.scitotenv.2020.140215 